\title{
A GEM-QUALITY IRIDESCENT ORTHOAMPHIBOLE FROM WYOMING
}

\author{
By R. V. Dietrich, John Sampson White, Joseph E. Nelen, and Kwo-Ling Chyi
}

A gem-quality iridescent orthoamphibole from Wyoming, similar to that described from Greenland, has been identified. This ornamental material occurs in a weathered gneiss-schist, near its contact with a peridotite mass. Most of the individual iridescent grains that constitute this rock are golden or dark brown, but a few are rose red or silvery gray. They consist principally of goethite and or opaline silica, which probably was derived directly from the original ferroanthophyllite as a result of weathering. Economic amounts of this material are not available at this time, although it is likely that the deposit has the potential to produce significant quantities.

Appel and Jensen's 1987 Gems \&) Gemology article on an "iridescent orthoamphibole" from Greenland reminded one of us (RVD) of a rock specimen and some cabochons (NMNH \# 120539) of Wyoming origin that were sent to the U.S. National Museum of Natural History (Smithsonian Institution) in the early 1960s. In 1987, we obtained additional hand specimens from this same locality. In total, three cabochons and six hand specimens, together with a couple of thin sections and several grain-mounts made from those specimens, were studied for this report (figure 1).

All specimens are from exposures about 11 miles $(18 \mathrm{~km})$ southwest of Douglas, in Converse County, Wyoming. Currently, there is little, if any, of the gem-quality material still exposed, but there may be significant amounts underground. If our hypothesized origin for the gem-quality material is correct, however, it probably occurs only in the upper few feet or, at maximum, few tens of feet of bedrock. In any case, additional material could

\section{ABOUT THE AUTHORS}

R. V. Dietrich is prolessor emeritus of geology a! Central Michigan University, Mt. Pleasant, Michigan; J. S. White is curator-incharge of gems and minerals, and J. E. Nelen is chemist, at the U.S. National Museum, Washington, DC: and K. L. Chyi is assistant prolessor of geology at Central Michigan Universily.

(c) 1988 Gemological Institute of America probably be collected with permission of the owner of the mineral rights, whose identity can be found by consulting records in the office of the county clerk in Douglas (R. B. Berry, pers. comm., 1987).

\section{GEOLOGIC SKETCH}

Mr. R. B. Berry, who collected and supplied us with the specimens studied, noted that the rock occurs as irregular masses within a weathered gneissschist, near its contact with a peridotite mass. This concurs with the geologic data of George L. Snyder, of the U.S. Geological Survey, who has mapped within the region (part of the Precambrian [Late Archean] metamorphic terrain of the northern Laramie Mountains). After examining one of our study specimens, Snyder wrote that he has seen similar amphibole-rich rocks associated with both amphibolite-grade iron-formation and calc-silicate rock in the Laramie Mountains. In addition, he suggested that "an iron-formation or a very impure carbonate rock may have been the metasedimentary wallrock progenitor that the reported peridotite intruded" (pers. comm., 1987).

\section{DESCRIPTION}

Like the iridescent orthoamphibole from Greenland, the material we examined (figure 2) is far from homogeneous. Rather, it consists for the most part of diversely oriented, nearly equidimensional amphibole( \pm ) grains that average about $1 \mathrm{~cm}$ across. Although most of the grains are golden or dark brown in color, a few are rose red; nearly all are iridescent (figures 1 and 3). A few sporadic silvery gray iridescent grains are also evident in some of the polished pieces (again, see figure 1).

The "amphibole $( \pm)$ " designation is given be-

\footnotetext{
After this report was submitted to Gems \& Gemology, a similar-appearing material was sent to the GIA Gem Trade Laboratory by Mr. Bill Martinek, of Martinek lewelers, Traverse City, Michigan, for identification. Chemical analyses by energy-dispersive X-ray fluorescence (performed by Carol Stockton, of the GIA Research Department), proved that this material-also purportedly from Wyoming $(V$. Hobe, pers. cornm., 1988)-was the same as that we examined. A photo of Mr. Martinek's specimen is included here as well (figure 3).
} 


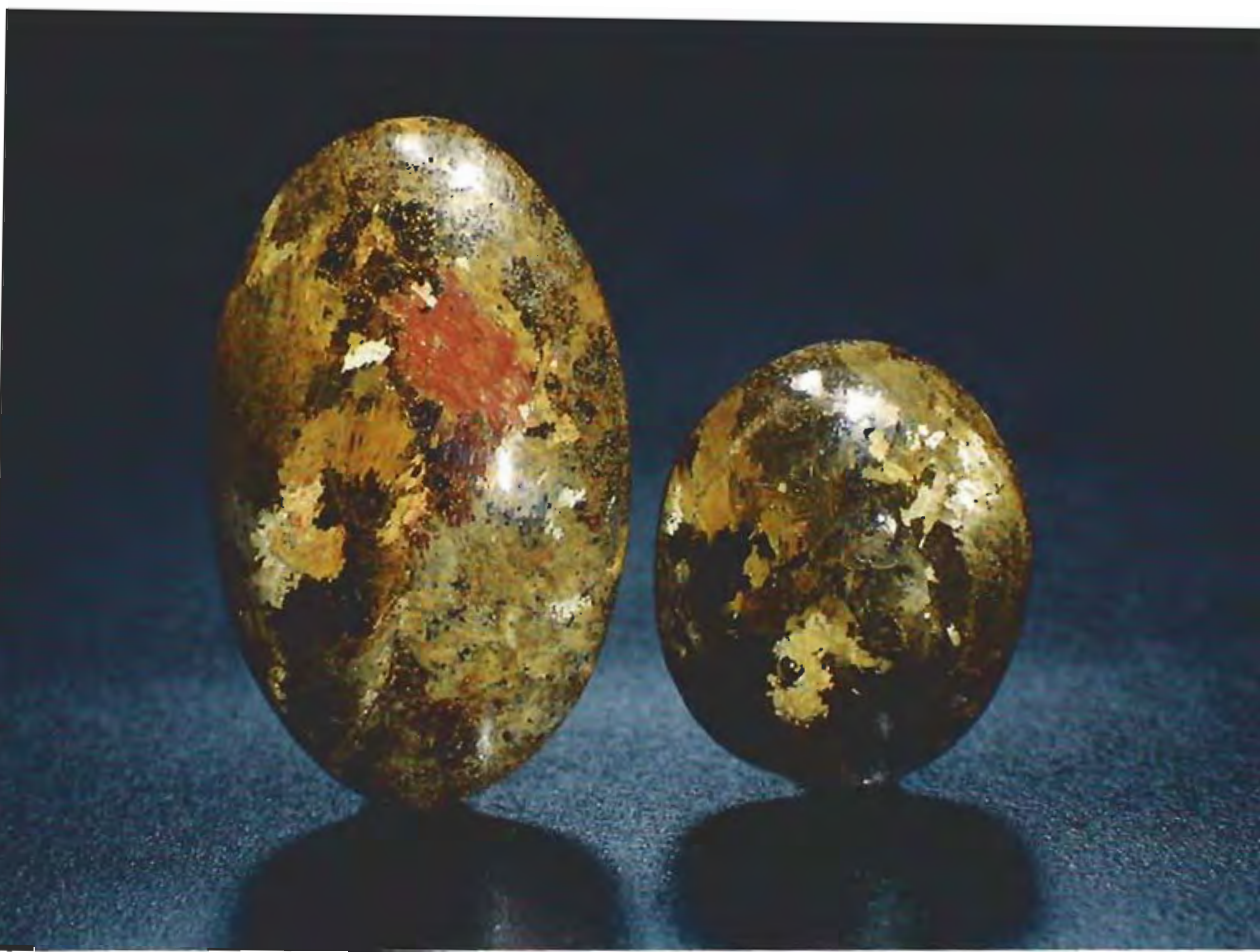

Figure 1. These are two of the cabochons of iridescent orthoamphibole from Wyoming that were examined for this report. The larger stone is $0.6 \times 2.5 \mathrm{~cm}$. Note especially the variety of colors in which the iridescent grains may appear. The larger specimen is courtesy of the U.S. National Museum of Natural History; photo by Robert Weldon.

cause the individual grains range from partially to completely dissociated to a mixture of goethite and opaline silica. The rock also contains small percentages of a few other minerals. The most common is garnet, which occurs as small grains, most of which are $0.1-0.2 \mathrm{~mm}$ across. Some of these garnet grains are discrete, whereas others constitute irregular aggregates that typically include 20 to 50 grains. Quartz veins, dense black goethite veins, and fracture surface coatings of white calcite are also common.

Some cabochons fashioned from this rock exhibit extremely attractive hologram-like effects. That is, some of the grains seem to be floating in an overall dark brown milieu.

\section{GEMOLOGICAL AND OTHER PROPERTIES}

Because this gem material is a rock rather than a mineral, gemological properties of practical use differ from those usually reported. Essentially, they consist of data for individual mineral constituents rather than for the material as a whole; these data are given in the succeeding paragraphs of this section. Furthermore, because of the variability of constituents, the density (usually reported as specific gravity) is not given here. For this rock, as for many mixtures of minerals, the density varies over so wide a range that it is of little significance. In fact, two essentially identical appearing specimens of this rock may have specific gravities that differ by as much as 0.5 in larger samples to 1.5 in smaller pieces.
None of this material fluoresces when exposed to long-wave ultraviolet radiation. It does, however, exhibit a dull, hardly detectable, orange to rusty red fluorescence to short-wave U.V.

Optical examinations indicate that the Wyoming rock once consisted largely of an orthorhombic amphibole (biaxial, $(+$ ), R.I. $-\gamma=1.667$; the small size and discoloration of the individual units of pure amphibole precluded determination of the lower $\alpha$ and $\beta$ refractive indices). Today, nearly all of the grains contain noteworthy percentages of goethite and opaline silica, and some are essentially all goethite and opal. The different phases occur as interdigitated mixtures with interrelations that resemble those exhibited by microperthites usually termed mesoperthites with shadow textures (see, for example, figures 19-2 and 19-17 in Smith, 1974). Typically, elongate masses of goethite and opal are essentially parallel to the $c$ crystallographic axes of the original amphibole grains. As viewed through a microscope, the goethite is golden to rusty brown in color, and is essentially opaque; the opacity makes determination of definitive optical properties impossible. The opal is optically isotropic and has a refractive index of $1.422 \pm 0.001$, which indicates that it probably has a relatively high $\mathrm{H}_{2} \mathrm{O}$ content.

$\mathrm{X}$-ray powder diffraction patterns corroborate the optical data. The amphibole generates good peaks, from which we calculated the following cell dimensions (in angstroms): $\mathrm{a}=18.82(5), \mathrm{b}=$ 18.23(7), $\mathrm{c}=5.29(1)$. (These dimensions were calculated by a least-squares refinement of nine 
indexed peaks; Charles W. Burnham's LCLSQMARK VI program was used.) This cell is significantly larger than that recorded by Appel and Jensen (1987) for the orthoamphibole from Greenland. The major goethite peaks from the Wyoming material - those with $\mathrm{d}(\mathrm{I})$ values of $4.18(100)$ and $2.69(30)$ - are distinct. We have observed no reflections that can be attributed to the opaline silica; however, the likelihood of its presence is indicated by, and probably responsible for, the rather high background present on X-ray patterns of the other minerals and mineral combinations.

Microprobe analyses " indicate that the Wyoming amphibole is ferroanthophyllite with the approximate formula $\left(\mathrm{Fe}_{6.23} \mathrm{Mn}_{0.42} \mathrm{Mg}_{0.35}\right)$ $\mathrm{Si}_{8} \mathrm{O}_{22}(\mathrm{OH})_{2}$, but also containing minor $\mathrm{Al}\left(0.02-0.97\right.$ wt. $\left.\% \mathrm{Al}_{2} \mathrm{O}_{3}\right), \mathrm{Ca}(0.29-1.12$ wt.\% $\mathrm{CaO}), \mathrm{K}\left(0.01-0.11\right.$ wt. $\left.\% \mathrm{~K}_{2} \mathrm{O}\right), \mathrm{Na}(0.03-0.25$ wt. $\%$ $\left.\mathrm{Na}_{2} \mathrm{O}\right)$, and $\mathrm{Ti}\left(0.06-0.11\right.$ wt. $\left.\% \mathrm{TiO}_{2}\right)$. This composition contrasts in several ways with the range of compositions recorded by Appel and Jensen (1987) for the Greenland orthoamphibole: $\mathrm{Na}_{0.17}$ $(\mathrm{Mg}, \mathrm{Fe})_{6.3} \mathrm{Al}_{0.7}\left(\mathrm{Al}_{0.9} \mathrm{Si}_{7.1}\right) \mathrm{O}_{22}(\mathrm{OH})_{2}$ to $\mathrm{Na}_{0.29}$ $(\mathrm{Mg}, \mathrm{Fe})_{6.3} \mathrm{Al}_{0.7}\left(\mathrm{Al}_{1,0} \mathrm{Si}_{7.0}\right) \mathrm{O}_{22}(\mathrm{OH})_{2}$. For the record, microprobe analyses indicate the garnets in the Wyoming! material to be Ca-bearing almandinespessartine. Their composition is approximately $\left(\mathrm{Fe}_{1.41} \mathrm{Mn}_{1.09} \mathrm{Ca}_{0.50}\right) \mathrm{Al}_{2}\left(\mathrm{SiO}_{4}\right)_{3}$ with $0.66-1.17$ wt. $\% \mathrm{MgO}, 0.0-0.04$ wt. $\% \mathrm{~K}_{2} \mathrm{O}, 0.04-0.07$ wt. $\%$ $\mathrm{Na}_{2} \mathrm{O}$, and $0.05-0.09$ wt. \% $\mathrm{TiO}_{2}$.

Microprobe reconnaissance traverses across the composite amphibole( \pm ) grains corroborate the optical data. That is, they show that these grains comprise thin /submicroscopic to about 0.1 $\mathrm{mm}$ ) bands of hairlike domains that consist primarily of iron and silica in near-ferroanthophyllite proportions, with alternate bands having excess amounts of either iron (goethite) or silica (opal) or both, plus a few bands that are almost wholly silica.

\footnotetext{
"ARL-SEMQ with six fixed spectrometers (Si, Al, Fe, $\mathrm{Mg}$, $C a$, and $K)$ and three scanning spectrometers, which were tuned for $\mathrm{Ti}, \mathrm{Mn}$, and $\mathrm{Na}$; operating voltage $-15 \mathrm{k} \mathrm{V}$, sample current $-0.025 \mu \mathrm{amp}$ on brass; all analyses were done with a focused beam and corrected for matrix effects using a Bence-Albee correction program; on-peak backgrounds were measured on corlundum for Si and on quartz for other elements. Hornblende from Kakanui, New Zealand (NMNH \#143965) was the primary standard used for amphibole analyses, and garnet from the Roberts Victor Mine, South Africa (NMNH \#87375) was the primary standard used for garnet analyses (see Jarosewich et al., 1980).
}

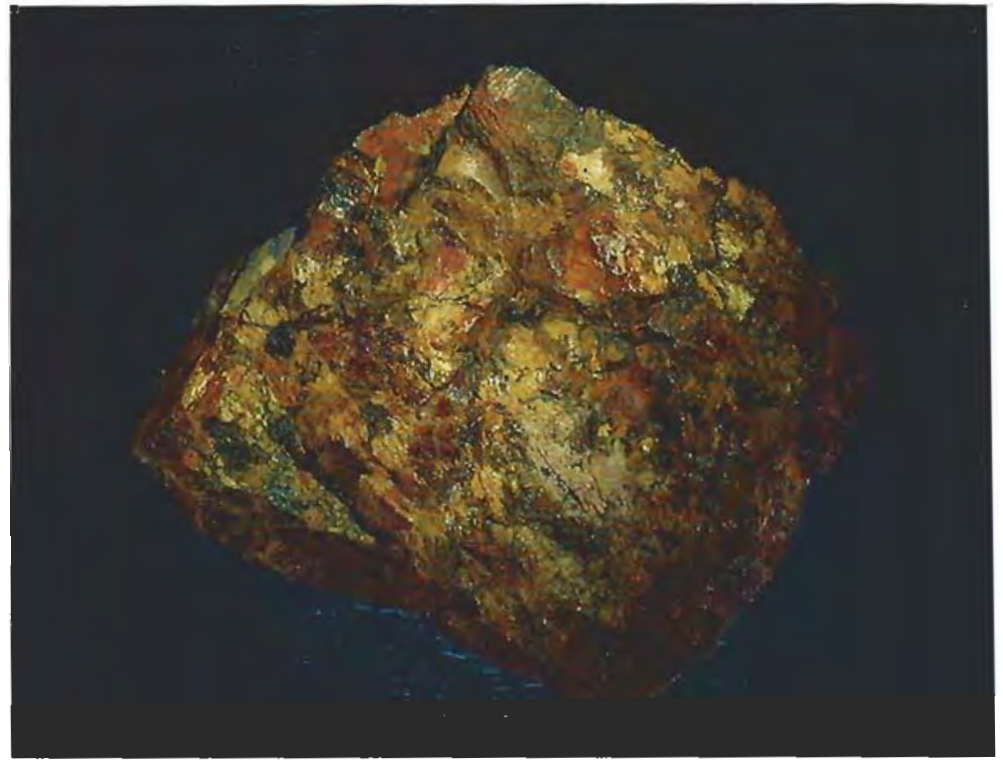

Figure 2. Unlike the material from Greenland, the iridescence of the Wyoming amphibole \pm ) rock is exhibited well in some hand specimens. Longest dimension is $9.5 \mathrm{~cm}$ (approximately 3/4 in.). Photo by Robert Weldon.

\section{CAUSE OF THE IRIDESCENCE}

The iridescence of this gem material appears to depend on diffraction of light by the intricate, more or less parallel arrangement of the extremely small masses of the diverse constituents of the amphibole( \pm ). The alternative that it might depend on

Figure 3. Typically, most of the grains in the iridescent orthoamphibole from Wyoming are golden or dark brown. Specimen $(1.1 \times 2.4 \mathrm{~cm})$ courtesy of Bill Martinek, Martinek lewelers; photo by Robert Weldon.

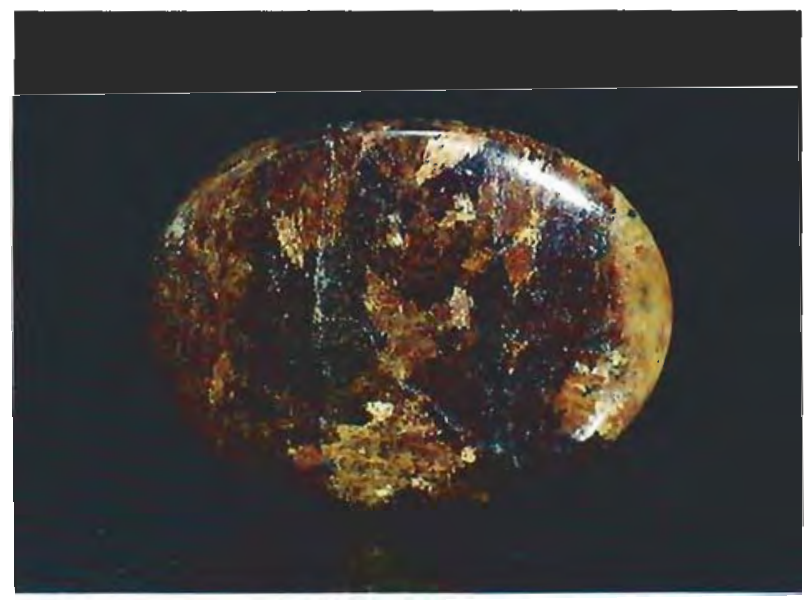


the presence of opal can be ruled out. Not only are most of the constituent masses of opal extremely small, but the silica spheres that constitute the opal also lack a regular arrangement such as that responsible for the diffraction of light that causes play-of-color in gem opal.

\section{ORIGIN OF THE BANDING}

The interrelationships among the mineral constituents indicate that the goethite and opal were very likely derived directly from the original ferroanthophyllite. The dissociation could have been a two-step process that involved, for example, a breakdown of the ferroanthophyllite to quartz and olivine, plus or minus magnetite, at elevated temperatures and pressures (Gilbert et al., 1982), followed by processes that resulted in the alteration of those minerals to the opaline silica plus goethite. We consider it more likely, however, that the dissociation was direct, that is, that the ferroanthophyllite was converted into opaline silica plus goethite, probably in response to near-surface, low-temperature/low-pressure weathering and weathering-associated processes. Geologic relations and considerations, along with the occurrence of ferroanthophyllite grains that are only partially dissociated close to grains that are largely opaline silica and goethite, have led us to this conclusion.

This possible derivation of goethite and silica-opal, in this case-as the result of the breakdown of an amphibole raised another question: Could some tiger's-eye consist of goethite and quartz derived as the result of a similar breakdown of its precursor asbestiform amphibole? In seeking a tentative answer to this question, we examined several tiger's-eye specimens. We found that some do indeed consist of alternate fibers of goethite and silica (quartz) rather than almost wholly of silica (quartz), as usually reported. Thus, it would seem that different tiger's-eye materials may be of different origins, and that some may be the result of an alteration similar to that hypothesized for the Wyoming material described in this article.

\section{SUMMARY AND CONCLUSIONS}

The gem material described herein was collected near Douglas, in Converse County, Wyoming. It is an altered amphibole-rich rock now made up largely of diversely oriented grains comprising intimately intermixed lamellae or hair-like units of goethite and opal plus or minus some of the original amplibole (ferroanthophyllite). The alteration is probably a result of weathering or weathering-associated processes. While this material is somewhat similar in appearance to the iridescent amphibole reported from Greenland, there are a number of differences in diffraction patterns and chemical composition.

The Wyoming rock has been cut and polished to make attractive cabochons that are predominantly golden to dark brown, with some of the stones also containing sporadic grains that are rose red or silvery gray. Grains of each of the colors are typically iridescent. The diffraction of light responsible for the iridescence appears to be caused by the extremely thin bands and/or hair-like masses of the constituent goethite and opal plus or minus the original ferroanthophyllite.

The amount of this material still available for recovery can only be guessed. Based on the hypothesized origin, we think that it may be significant, although it is very likely restricted to the relatively thin zone of weathering.

\section{REFERENCES}

Appel P.W.U., lensen A. (1987) A new gen material from Grecnland: Iridescent orthoamphibole. Gems \& Gemology, Vol. 23, No. 1, pp. 36-42.

Gilbert M.C., Helz R.T., Popp R.K., Spear F.S. \{1982\} Experimental studies of amphibole stability. In D. R. Veblen and P. H. Ribbe, Eds., Reviews in Mineralogy, Volume 9B. Anphiboles: Petrology and Experimental Phase Relations, Mineralogical Society of America, Washington, DC, pp. 229355 (see especially p. 236).

Jarosewich E., Nelen J.A., Norberg J.A. \{1980\} Reference samples for electron microprobe analysis. Geostandards Newslet ter, Vol. 4, pp. 43-47.

Smith J.V. (1974) Feldspar Minerols: 2, Chemical and Texturat Properties, Springer-Verlag, Now York. 